Journal of Information Systems Engineering \& Management, 2:1 (2017), 6 ISSN: 2468-4376

\title{
Learning Information Systems: Designing Education Programs Using Letrinhas
}

\author{
Célio Gonçalo Marques ${ }^{1 *}$, António Manso $^{2}$, Ana Paula Ferreira ${ }^{3}$, Felisbela Morgado ${ }^{3}$, Marco Gaspar ${ }^{2}$ \\ ${ }^{1}$ Instituto Politécnico de Tomar, PORTUGAL; Universidade de Lisboa, PORTUGAL; Universidade de Coimbra, \\ PORTUGAL \\ ${ }_{2}^{2}$ Instituto Politécnico de Tomar, PORTUGAL \\ 3 Agrupamento de Escolas Artur Gonçalves, PORTUGAL
}

*Corresponding Author: celiomarques@ipt.pt

Citation: Marques, C.G., Manso, A., Ferreira, A.P., Morgado, F. and Gaspar, M. (2017) Learning Information Systems: Designing Education Programs Using Letrinhas, Journal of Information Systems Engineering \& Management, 2:1 (2017), 6.

doi: http://dx.doi.org/10.20897/jisem.201706

Published:

\begin{abstract}
The Letrinhas information system contributes to the improvement of students' reading literacy combining the potential of mobile devices and the specific needs of students and teachers. This information system has emerged within the framework of a partnership established between the Instituto Politécnico de Tomar (IPT) and the Artur Gonçalves Cluster of Schools, in Torres Novas, Portugal.

After three years of the creation of the tool and its use in a real learning environment, the evaluation already carried out suggests a high degree of satisfaction on the part of teachers and students, as well as a very positive impact on improving the reading skills of the students involved in the project.

The latest version of Letrinhas has new features which lead to the specific challenges and needs of the teachers in the above-mentioned cluster of schools. Being so, in addition to the evaluation and improvement of reading skills, the new version provides features that enable the creation of educational scenarios promoting learning environments that enhance, not only the autonomy of students, but also their motivation.
\end{abstract}

Keywords: information systems, education, learning, Letrinhas, mobile devices

\section{INTRODUCTION}

The development of applications enabling to detect and help students with reading difficulties has proved crucial (Carvalho, 2011; Lopes, 2005; Velasquez, 2007), as the studies conducted in this area demonstrate that there is a close relationship between reading literacy and the quality of learning.

Therefore, the acquisition of reading literacy skills is an essential condition for the academic success of students, as it determines their ability to learn in the various subject areas. "The command of written language increases communication capability and is simultaneously the great enhancer of learning as well as of the development of individual interests and the cognitive capacity of individuals (readers)" (Sim-Sim, 1995, p. 203).

Learning to read in the early stages of education is a complex and determinant task for the development of proficient readers. Given its complexity (Manso et al., 2015), the learning process of reading can, for many students, be slow and time-consuming, often bringing out feelings of frustration and low self-esteem. That's why some authors (Cruz, 2016; Shaywitz, 2008) have supported the idea that action to deal with reading difficulties should focus on three main aspects: 1) early detection; 2) prevention; 3) re-education. In fact, the results of studies that have been conducted show that the success rate will be greater the sooner you detect learning problems. As a 
conclusion, one can state that the implementation of reading programs should take place in the first two years of schooling (Foorman, Francis, Shaywitz \& Fletcher, 1997).

It is therefore mandatory to identify children at risk for reading difficulties and ensure that all actions to assess reading literacy will put students on a scale of performance and will effectively act on the problems identified (Manso et al., 2015).

In the government guidelines for the teaching of Portuguese in basic education (Programa e Metas Curriculares de Português do Ensino Básico), which entered into force in the 2015/2016 school year, reading and writing aim at developing reading fluency (i.e. speed, accuracy and prosody), vocabulary, reading comprehension, gradual text production and comprehension. The gradual increase in the level of complexity is clear in these goals, especially in reading fluency.

\begin{abstract}
"Read a text with a reasonably appropriate pronunciation and intonation and a speed of at least: 1 st grade: 55 words per minute; 2 d grade: 90 words per minute; 3 rd grade: 110 words per minute; 4 th grade: 125 words per minute" (Buescu, Morais, Rocha \& Magalhães, 2015, p. 45).
\end{abstract}

The given example very well shows the need to use tools that validate and promote the necessary conditions to ensure the improvement of this skill in students with reading difficulties (Manso et al., 2015).

In order to find solutions to specific problems of students, properly diagnosed at class council meetings, and to respond to the need of developing skills to become critical and engaged citizens to face the 21st century challenges, the school libraries of the Artur Gonçalves cluster of schools (Torres Novas, Portugal), as innovative learning centres, created the project "Teaching and Learning with School Library".

This project which includes a reading-oriented strand - the "Gym of Readings" - and was considered by the school libraries network as an "Ideas with Merit Project", led the network to invite the Polytechnic of Tomar to come up with a solution based on information technologies that could help address the reading difficulties identified by the teachers, as there was no suitable software available in the Portuguese market.

In the year 2014, the teachers and students of the undergraduate degree in computer engineering from the Polytechnic Institute of Tomar accepted the challenge and began to develop the Letrinhas information system. This research work aims to promote learning and the development of reading literacy in students of the 1st and 2nd stages of basic education and provide teachers with tools for monitoring and assessing reading literacy.

The information system once created, it has been assessed by experts in the area and future users and validated by proof-of-concept by teachers and students. In 2015 a case study with Letrinhas has been carried out in one of the schools in the cluster. The positive impact on improving learning in the students involved and the high degree of satisfaction of its users (teachers and students), coupled with the potential of mobile technologies, has created a new challenge: expanding Letrinhas to learning content of any subject area, suited to individual students and with automatic content evaluation. The new version of Letrinhas allows to create new learning scenarios, placing the student at the centre of the whole process and the teacher as a facilitator of learning (Manso et al, 2015). This paper describes the new version of Letrinhas and presents results of its use and evaluation.

\title{
PROMOTING LEARNING THROUGH MOBILE DEVICES
}

In order to achieve student success, it is essential that teachers promote and encourage a love for reading and adopt innovative and creative pedagogical practices inside and outside the classroom that help develop reading literacy (Lamas \& Neto, 2015).

According to Lamas and Neto (2015, p. 141) "we need a dynamic ever-evolving teaching that helps students develop skills that will prepare them to face the challenges of the new twenty-first century society". In this context, information and communication technologies (ICT) have huge potential, providing more creative, motivating and effective learning scenarios.

ICTs provide students with a more active role in the construction of knowledge and "studies have found that computer use enhances children's fine motor skills, alphabet recognition, concept learning, numerical recognition, counting skills and pre-mathematical knowledge, cognitive development, and self-esteem or self-concept" (Li \& Atknis, 2004, p. 1716).

In this "new world" encompassing new forms of teaching and learning enhanced by ICT "the use of mobile devices has, according to various studies, revealed to be the one with the greatest potential and the one that will have the biggest impact on education, with a view to adapting it to the 21st century challenges" (Pinheiro, 2016).

A growing number of projects in this area have demonstrated this potential. In international terms, Moura (2010) highlights, among others: Mobile Learning: The Next Generation of Learning, Minerva AlphaBeta, MOBIlearn, UniWap, MyArtSpace, KMI@TMI5, K-Nect and Wireless Reach. In Portugal, the following projects stand out: TEA - Tablets no Ensino e na Aprendizagem (EN: TEA - Tablets in Teaching and Learning) Sala de 
aula Gulbenkian: entender o presente, preparar o futuro (EN: Gulbenkian classroom: understanding the present, preparing the future); Comunidades Escolares de Aprendizagem Gulbenkian XXI (EN: Gulbenkian XXI School learning communities); Edulabs; Creative Classrooms Lab and ManEEle (Manso et al., 2015).

In a questionnaire administered by Pearson in basic and secondary schools in the United States, $81 \%$ of the students agree that the use of tablets allows them to learn "in a way that's best for them" and $79 \%$ report that they help them "to do better in class" (Poll, 2014, p. 11).

This new way of teaching and learning, known as mobile learning, or m-learning, is fostered by the strong growth of mobile devices. According to Sterling (2016) "Mobile now represents 65 percent of digital media time, while the desktop is becoming a "secondary touch point" for an increasing number of digital users". In Portugal at the end of the second quarter of 2016, the penetration of mobile phone service amounted to 163 per 100 inhabitants (ANACOM, 2016).

Mobile learning, i.e., "the acquisition of any knowledge and skill through using mobile technology, anywhere, anytime, that results in an alteration in behaviour" (Geddes, 2004, p. 1) is more than the expansion of traditional teaching forms as an alternative learning process founded on instruction methods that promote autonomy and elearning as referred by Coutinho (2013). According to UNESCO (2014, p. 42) "as the power and functionality of mobile technologies continue to grow, its usefulness as educational tools probably will increase and, with its central role for education, both formal and informal".

Among the areas where mobile technologies have played an important role is the promotion of reading. "The potential of mobile technologies is even greater when it comes to language learning, since it contributes to the development of some or even all the basic skills" (Moura, 2010, p. 3). In this area there have been various applications to promote reading literacy, with many positive results both in terms of mother tongue and foreign languages, as in the case of GraphoGame (Richardson \& Lyytinen, 2014) and MPAL-Mobile-device-supported Peer-Assisted Learning (Lan, Sung \& Chang, 2007), as well as various studies on the subject (Larson, 2007; Pellerin, 2014; Thoermer \& Williams, 2012). All these studies support Mellati's and Khademi's thesis (2015) that "employing technological devices in language learning improves the quality of education" (p. 19).

Despite this technological evolution, through an analysis performed to applications for mobile devices available in Portugal (Manso et al., 2015), we found that none of them facilitated the evaluation of reading skills according to the national guidelines for the teaching of Portuguese at the basic education level. On the other hand, they did not allow to choose the texts to be included, selected according to the needs of each individual student, or the monitoring of learning. These needs gave rise to the Letrinhas information system. .

The success of this system in the area of mobile technologies applied to teaching and learning reading skills led to the expansion of the Letrinhas to other curricular areas, turning it into a tool with enormous potential at the level of basic education.

\section{THE LETRINHAS INFORMATION SYSTEM}

Letrinhas is an information system consisting of a digital repository of educational content and multi-platform application designed to work on mobile devices using touch-screen interfaces.

In the definition of the initial system requirements it was clear that the mobile application would have to work in environments where access to data networks are not available and, therefore, the tool is equipped with an automatic data synchronization system. This process is transparent to the user and whenever the mobile application accesses the Internet it synchronises their local databases with the database server. Another important requirement in mobile application is its adaptability to various devices including several types of resolutions and different operating systems. No less important is the financial issue and, therefore, open-source software technologies have been chosen so as the tool is available free-of-charge for users.

At first, the aim of Letrinhas was to provide teaching/learning resources that would promote the development of reading skills in students and help teachers to monitoring learning outcomes. However, with the development of the tool, it became clear that the initial features could be expanded to cover other subjects and to evaluate other capabilities in addition to reading. Thus, educational content was defined exploiting the multimedia capabilities of mobile devices to teach and evaluate.

\section{Teaching and Learning Elements}

Several studies show that the simultaneous stimulation of multiple senses enhances learning success. The Letrinhas makes use of the ability of mobile devices to reproduce sound and videos and present images and texts to enrich the assessment and learning elements.

Below are some of Letrinhas' learning and assessment features: 


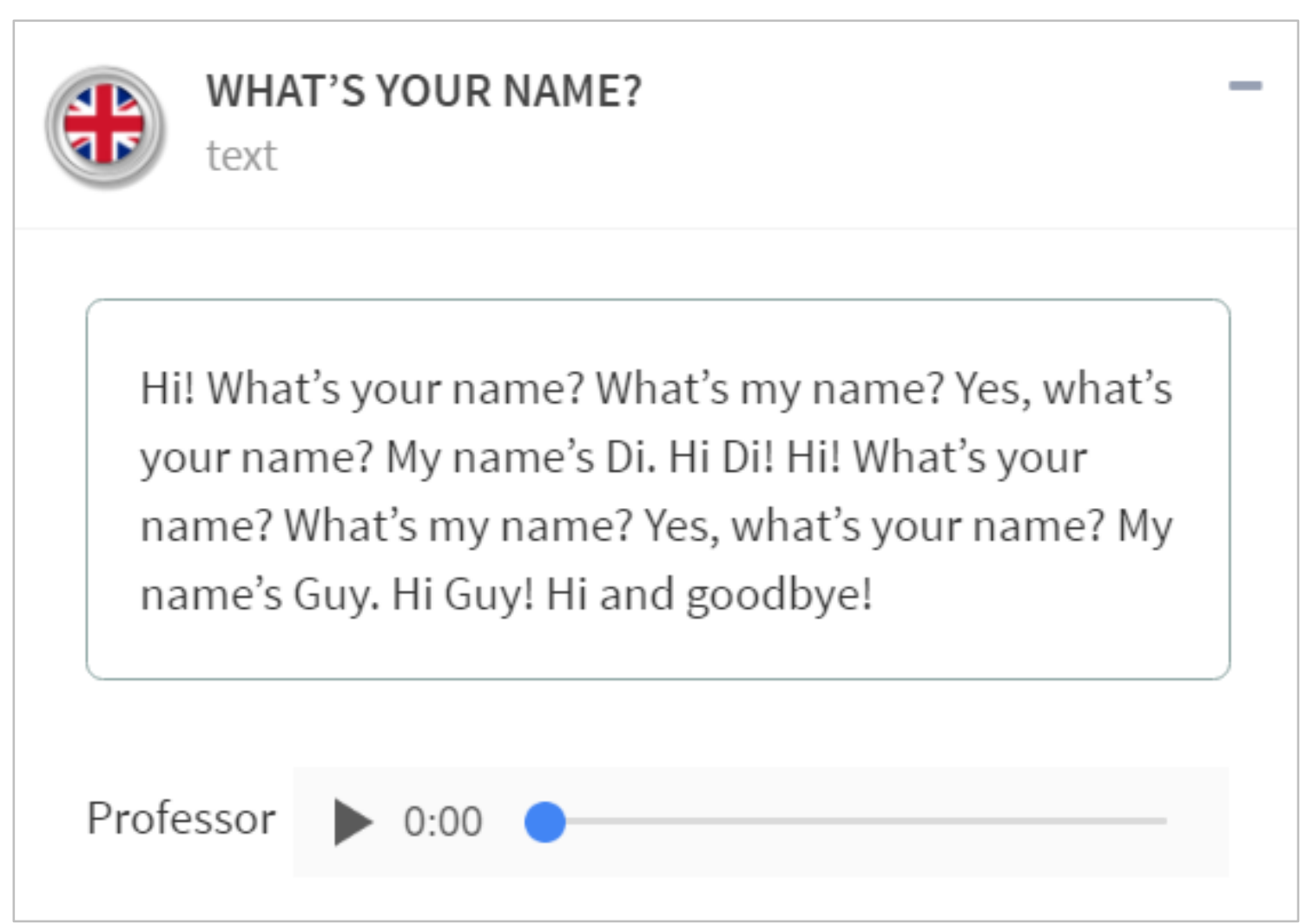

Figure 1. Text reading question

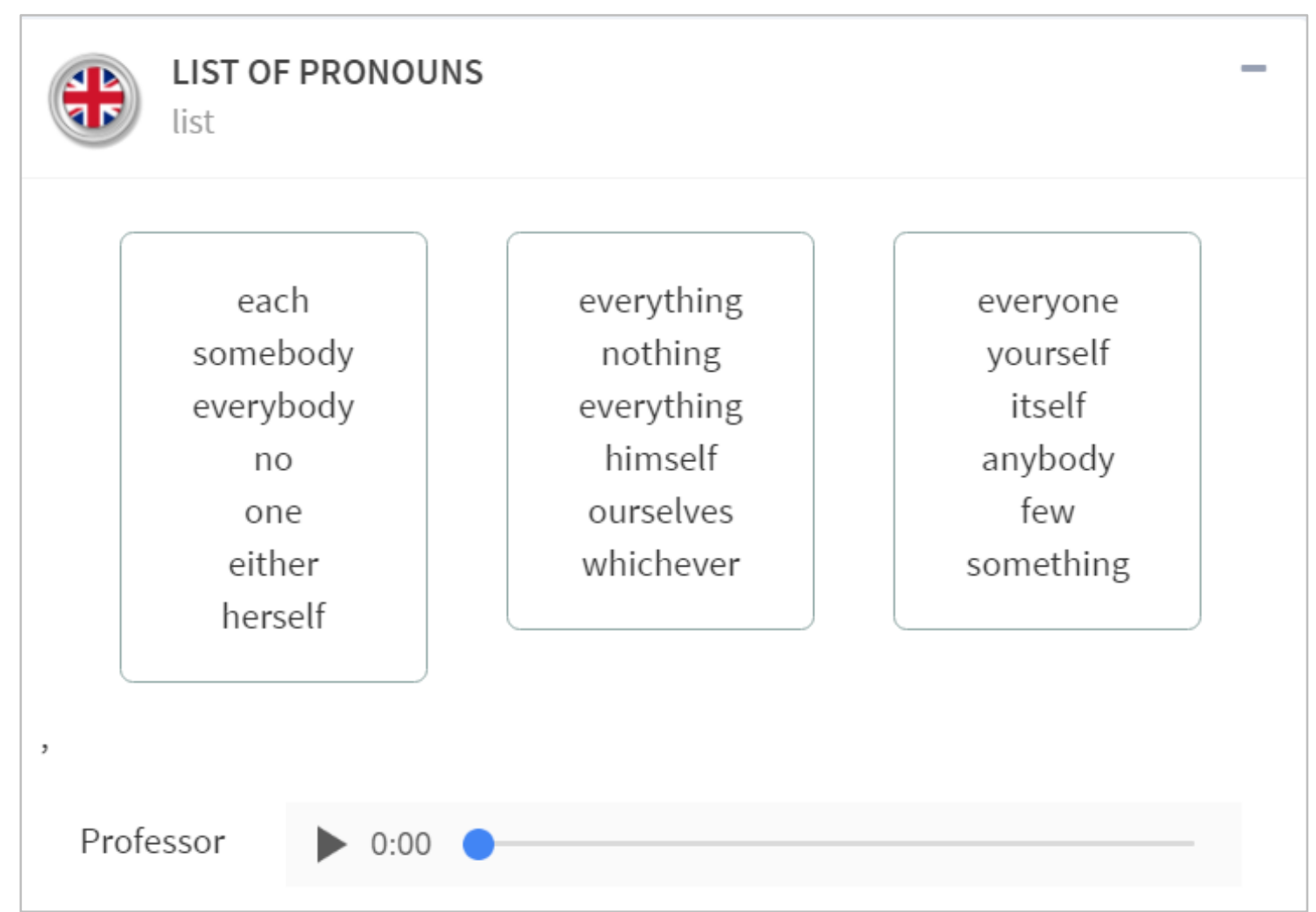

Figure 2. Word list question

\section{1) Reading Elements}

The text reading questions, Figure 1, allow students to learn to read fluently and teachers to evaluate the fluency of reading both in the mother tongue and in foreign languages.

The reading test has the recorded teacher's voice, which enables students to hear the correct intonation, speed and prosody and try to repeat and record their own voices.

The Letrinhas also allows testing where the texts are presented in the form of lists of related words (Figure 2). 


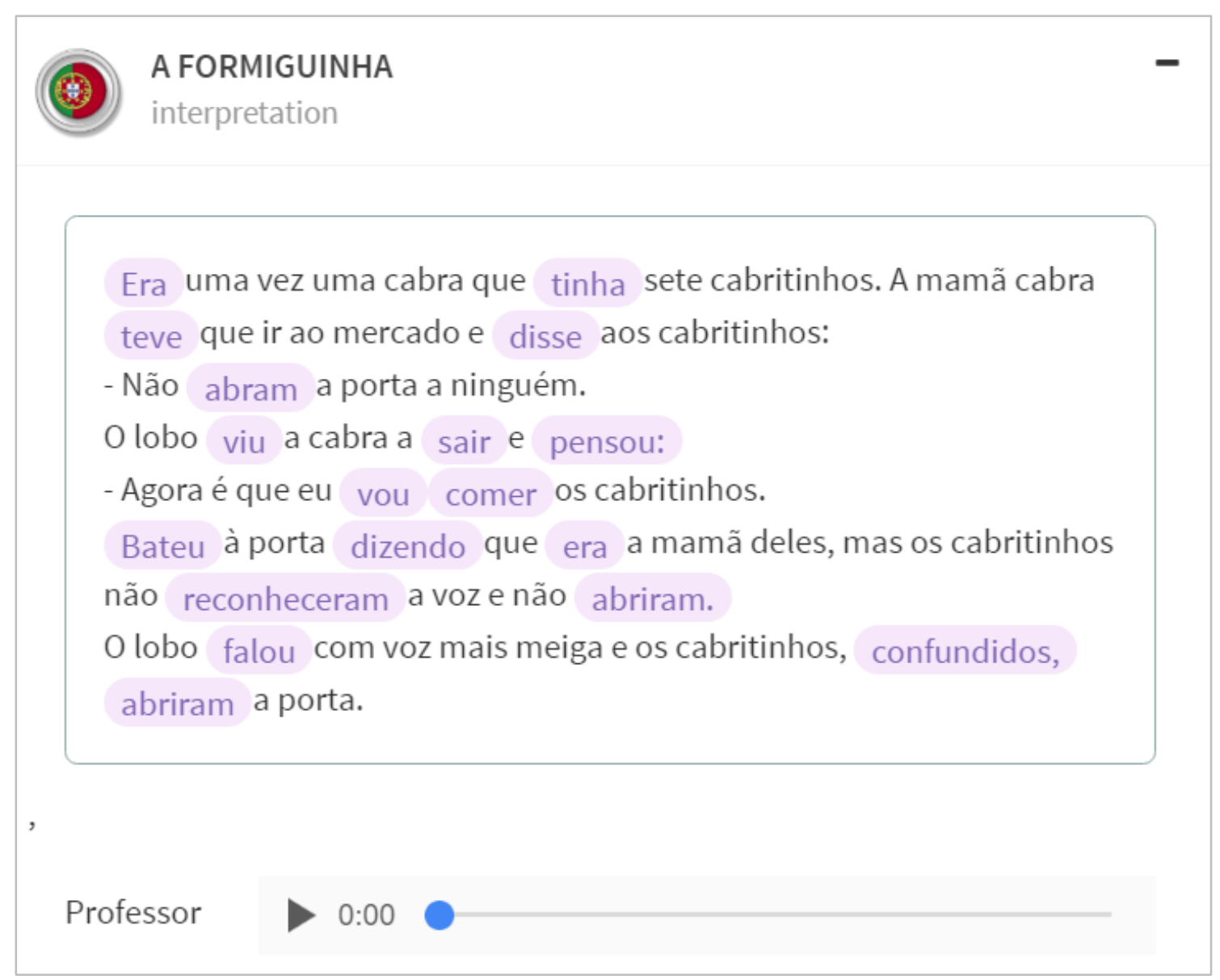

Figure 3. Word selection test

During the test, students read the text and the tool records their voice. They can then play the recording back and repeat the test if they are not satisfied with the result. The fact of them being able to hear their own voice allows them to identify their difficulties and try to overcome them by themselves.

Students can listen to the teacher reading as many times as needed and the text has a voice synchronization system that allows them to associate the words they are hearing with the words in the text. Establishing a connection between words and sounds, these tests stimulate sight and hearing at the same time to make the learning process more effective. This association is particularly important in the learning of foreign languages in which the spelling and phonetics are different from the native language of the learners.

The fix for this kind of problems has to be done by teachers, but the tool facilitates this task. In the test, the students record their voice and the teacher can listen to it as many times as needed, especially the parts where the student made mistakes in order to clear any doubts.

\section{2) Self-correcting elements}

Text elements allow to teach and evaluate reading literacy, a key learning skill, but they have two limitations: they cannot be used in classroom context because correct sound capture requires a quiet environment and its assessment requires teacher intervention.

In order to expand the use of the tool, other self-correcting elements have been defined. This allows students to assess their knowledge right after the test.

In the context of reading two elements have been set that allow to teach and assess reading-related content (Figure 3).

- Word selection - Students are asked to select words in a text such as verbs, adjectives or other class of words.

- Entry of words - In this type of test students are asked to select one word to a blank in the text, such as punctuation, verb tenses or any other word lists.

Both elements are accompanied by text reading, which can help students to understand the question, and by the right answer which will allow the tool to make the correction.

Outside the scope of reading the Letrinhas is equipped with multimedia tests which, taking advantage of the multimedia capabilities of mobile devices, enable the assessment of any subject content. Figure 4 shows a set of 


\section{B. MUSICAL INSTRUMENTS}

(av) multimedia

Professor

0:00/0:05

4)

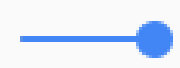

(1)

\section{(1)}
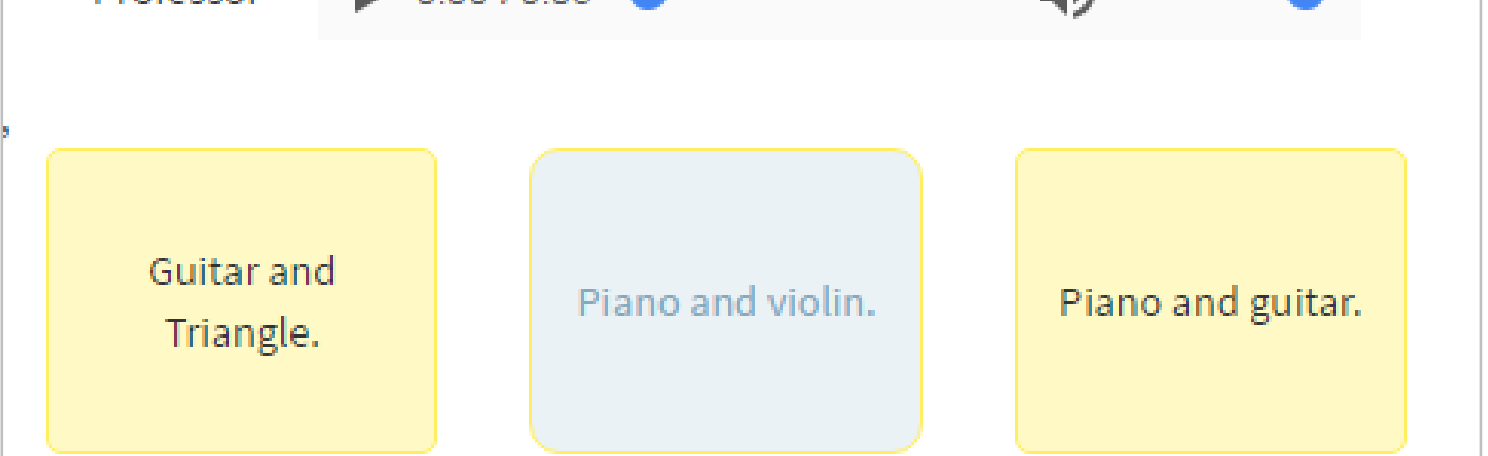

Figure 4. Multimedia question

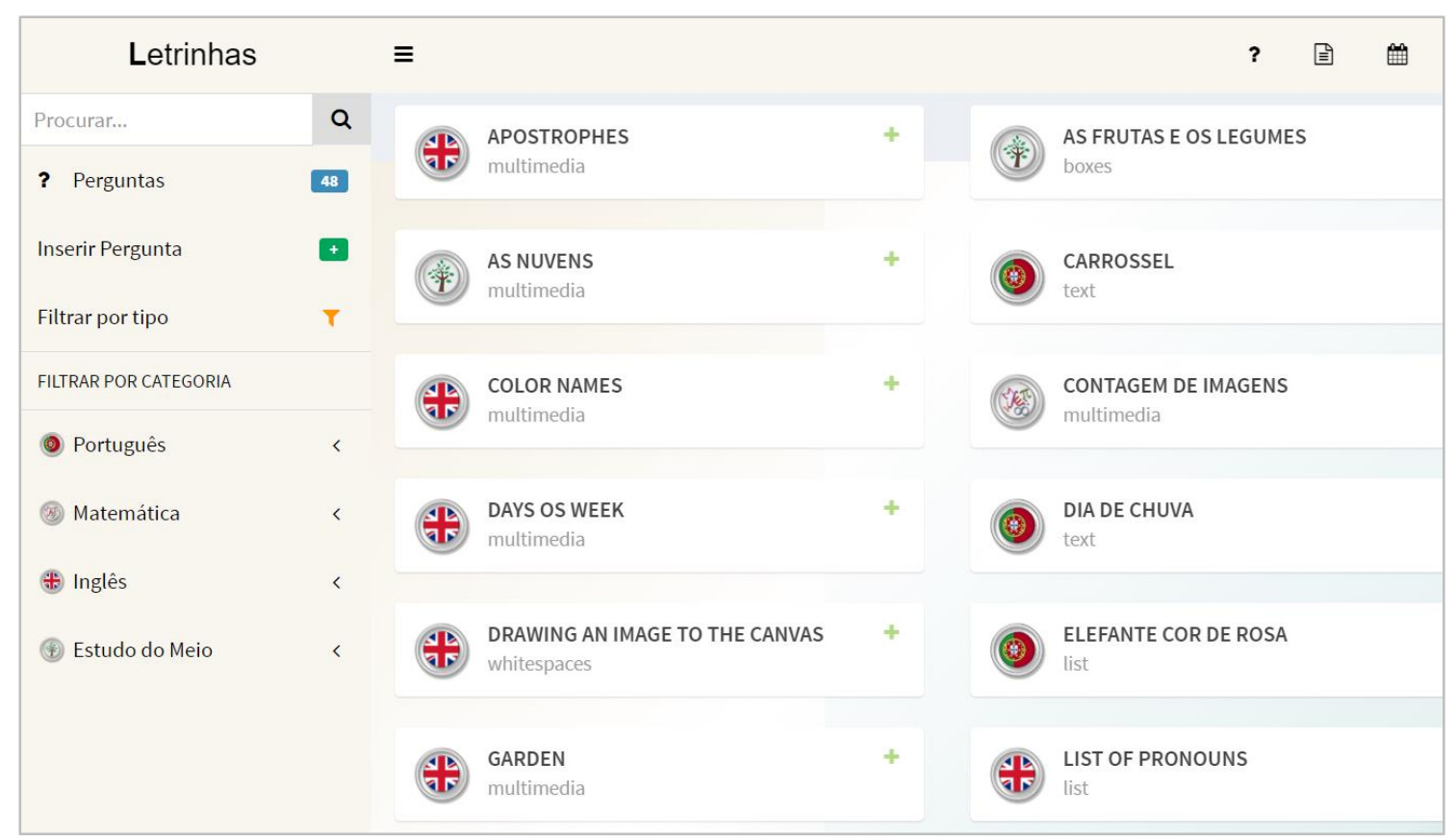

Figure 5. Question repository

multiple-choice questions. In the multimedia questions the teacher can use text, image and sound in the question body and text and image in the answers. These tests enable students to match sounds, pictures, and words.

\section{Digital content repository}

Didactic content is stored in a digital repository that promotes development and sharing of pedagogical content among teachers. The repository consists of questions and tests that comprise a set of questions.

Figure 5 shows the question repository in which teachers can enter, change, and delete questions.

The questions have multiple descriptors with filters so that teachers can find them and use them in the tests. After the teacher has grouped the questions in a test, the student is given access to it through a mobile device (Figure 6) after having introduced his/her credentials. Before assigning the test to the student, the teacher sets the time window in which the test becomes available, which allows access outside school time and through mobile devices. 


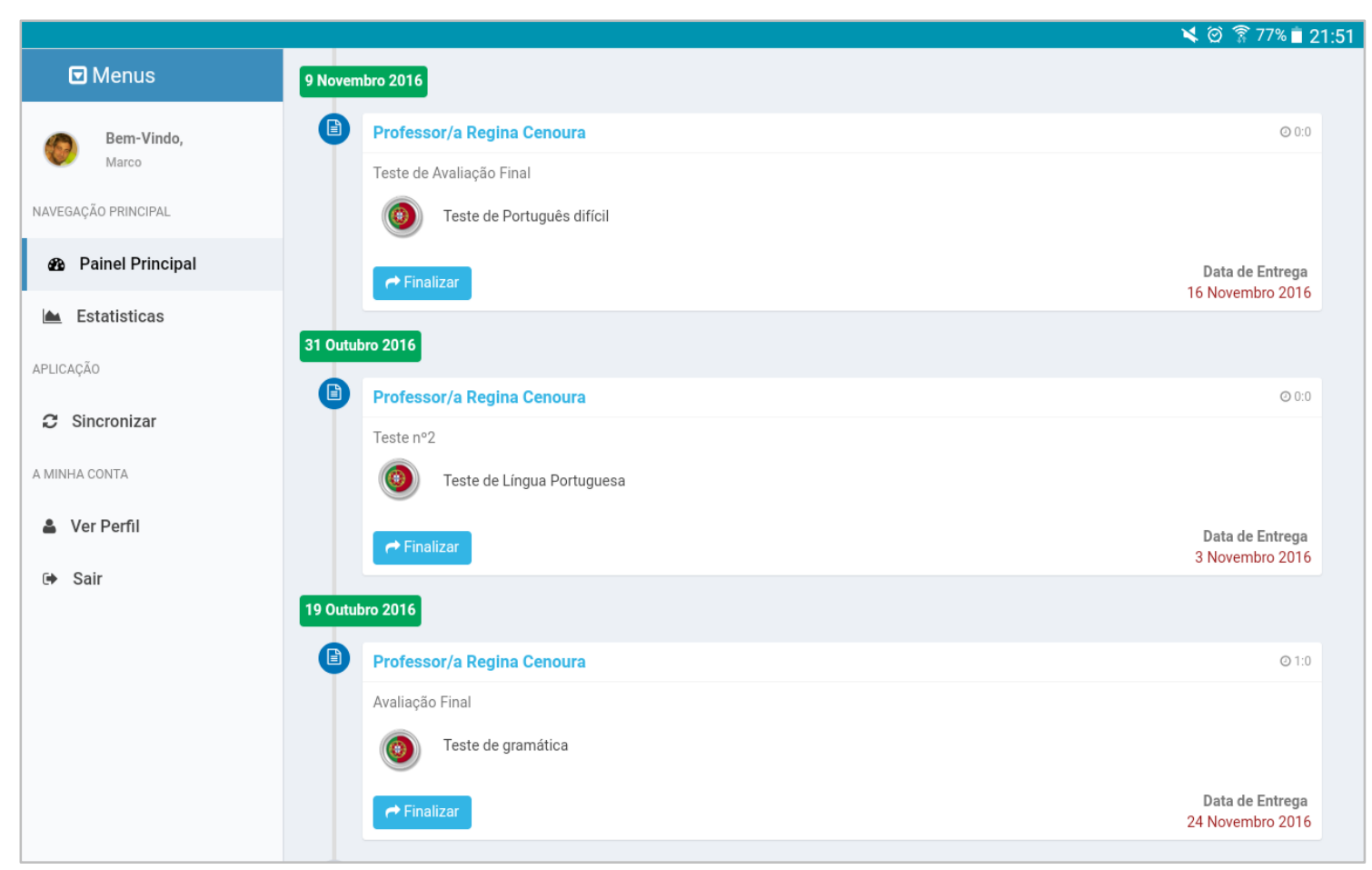

Figure 6. Mobile application

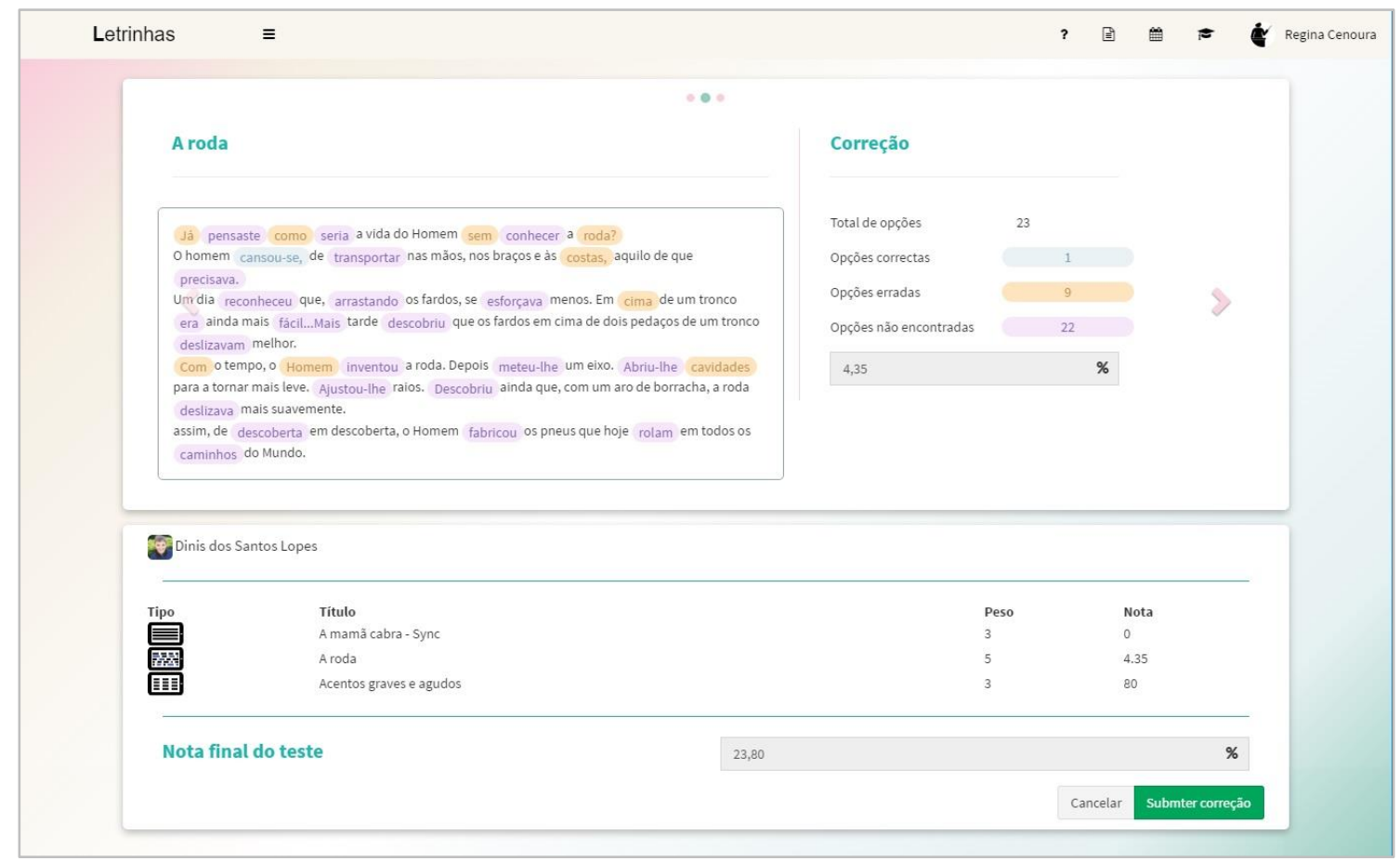

Figure 7. Automated error-correction in a reading test

\section{DESIGNING EDUCATION PROGRAMS USING LETRINHAS}

The diversity of features available in the tool, as well as its technical characteristics, which allow the teacher to manage the whole process of learning in the back office and its autonomous use by students contribute to the definition of various learning programmes adapted to the specific profile of the students and the type of use: individual, collective, group, in class or at home.

In this way, the conditions are created for the implementation of new learning environments, including the flipped classroom (Bergmann \& Sams, 2012), in which students take an active role in interactive activities making use of mobile technology. 


\begin{tabular}{|c|c|c|c|c|}
\hline Letrin & & $\equiv$ & ? 圆 些 & Regina Cenoura \\
\hline \multirow{11}{*}{$\begin{array}{l}\text { Procurar... } \\
\text { ? Perguntas } \\
\text { Inserir Pergunta } \\
\text { Filtrar por tipo } \\
\text { Flurpap Por categ }\end{array}$} & a & PORTUGUÊS & & - \\
\hline & a & & & \\
\hline & - & Gramática 15 Espectificasóes & & + \\
\hline & T & 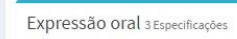 & & + \\
\hline & & & & \\
\hline & & Semântica 3 Espectificasces & & + \\
\hline & & Fonética 2 Especcificaşes & & + \\
\hline & & Inserir conteúdo de Portugués & & Adicicinar novo conteùdo \\
\hline & & $\begin{array}{l}\text { (20) MATEMática } \\
4 \text { Conteudos }\end{array}$ & & + \\
\hline & & (40) INGLÊs & & + \\
\hline & & (7) ESTudo Do MElo & & + \\
\hline
\end{tabular}

Figure 8. Subject selection

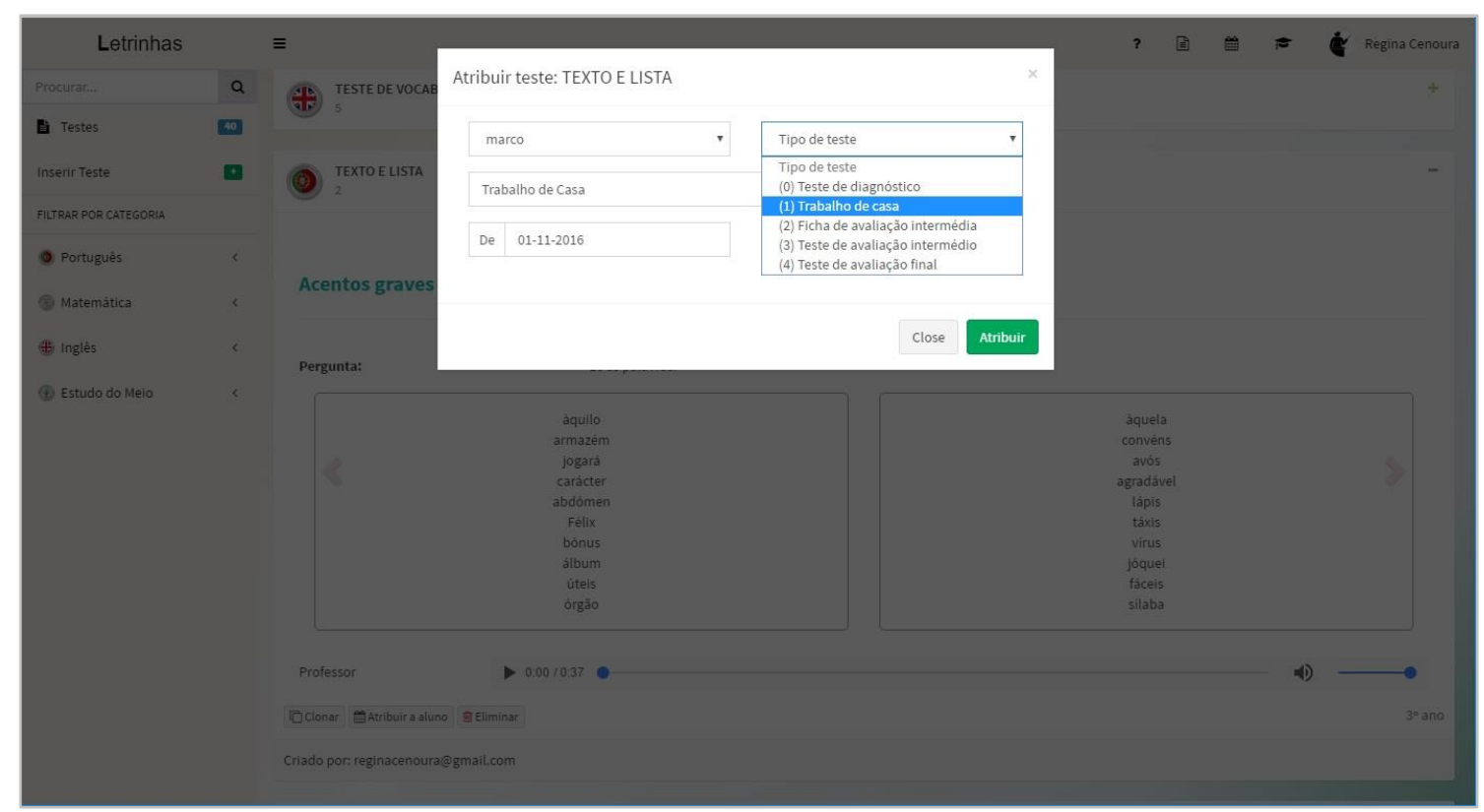

Figure 9. Assignment of activities to students

As Bergmann and Sams (2014) have highlighted, a learning environment of this kind is based on four assumptions that fit the Letrinhas information system: the flexible environment, the learning culture, the purpose of the content and the active role of the teacher.

In fact, this versatility of the tool, in addition to initial needs identified by the teachers in the Arthur Gonçalves cluster of schools, also allows to design new learning environments, which can be used independently by students, in the classroom or at home, because Letrinhas, in addition to being extended to other subjects (Figure 8) and at other levels of education, will be made available to students on their mobile devices.

The planning of the work to be carried out with the students is defined by the teacher in charge because it is he/she who creates the back-office tests enabling to tailor the activities and/or exercises to different levels and learning speeds as well as multiple education strategies (Figure 9).

In addition, the tool allows assessment and real-time monitoring of learning with numerous advantages, not only to the teacher's work, but mainly to the definition of the methodology to be defined for each individual student taking into account his/her learning difficulties or achievements (Figure 10). 


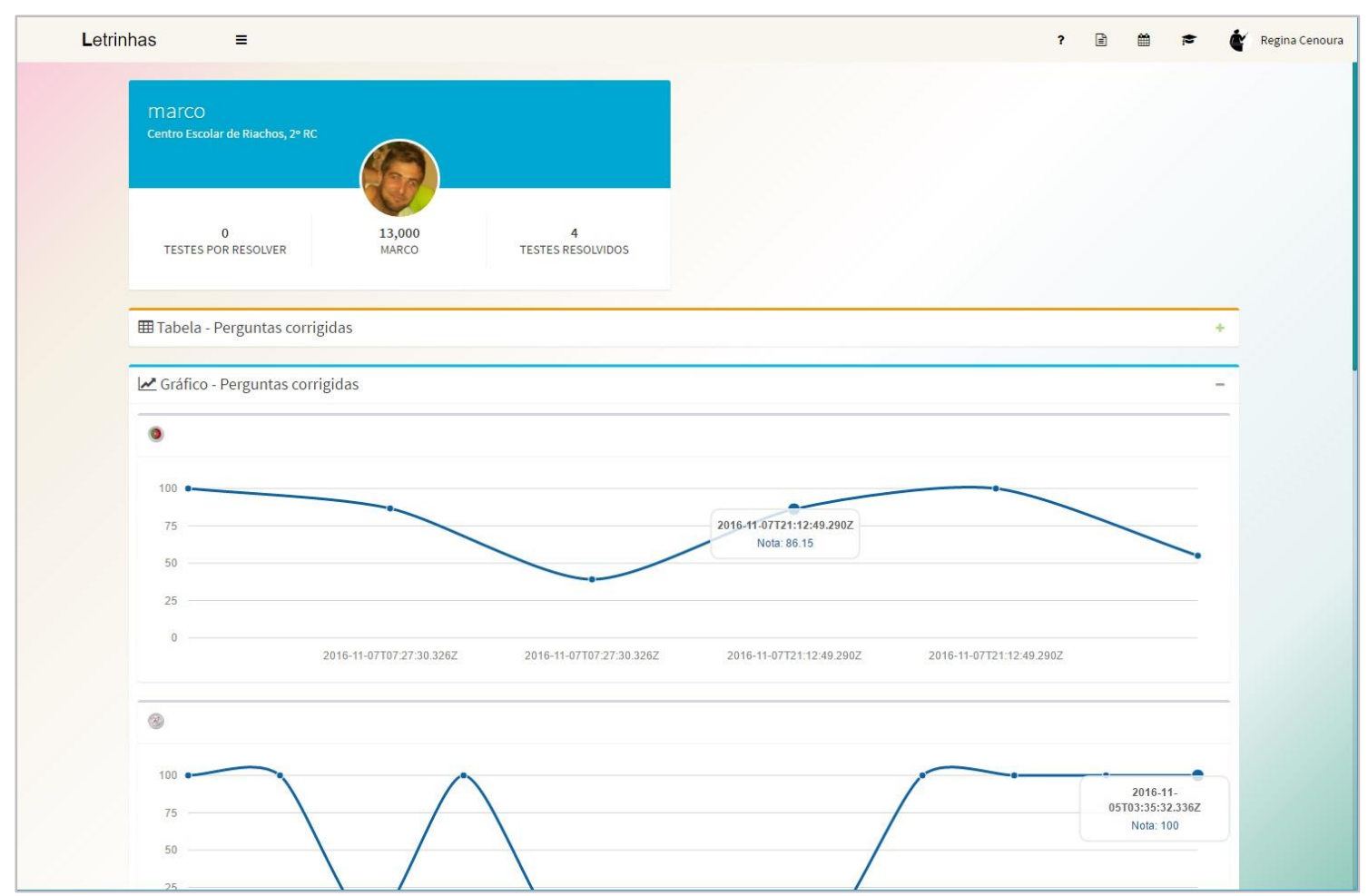

Figure 10. Student learning monitoring

The partnership established between the Artur Gonçalves cluster of schools and the IPT was paramount in this creative journey that resulted in the Letrinhas. The constant feedback between the two partners made it possible to create the different features and continuously improve the information system, adapting it to the real needs of the teachers and, consequently, of the students themselves.

\section{PRESENTATION AND ANALYSIS OF RESULTS}

The use of Letrinhas in a real learning environment started in 2015/2016, with a second-grade class of the abovementioned cluster of schools preceded by a period of assessment of the tool's usability. In this school year, the latest version of the tool is being used in all 2nd grade classes of the group.

\section{School year 2014/2015}

In the school year 2014/2015 the usability of Letrinhas has been assessed by experts in the field and by future users. Heuristic evaluation has been used as evaluation method, i.e. experts identified the problems based on the usability principles that were not complied with. Tests involving users enabled to identify errors that were corrected immediately, in addition to some improvements based on the feedback of the users.

The heuristic evaluation involved 3 experts and testing with users involved a class of second graders and their teacher, as well as 3 tutors from the Artur Gonçalves group of schools.

\section{School year 2015/2016}

\section{a) Pilot study}

In order to assess the impact of the tool on the improvement of students' reading literacy, a pilot study has been conducted in one of the schools in the cluster, in the school year 2015/2016. Twelve students participated in this study, five boys and seven girls, from the two 2nd grade classes of this school centre, duly identified by the teachers in charge as having reading difficulties. Students used the Letrinhas on a weekly basis throughout the whole school year and were accompanied by a tutoring teacher.

The aim was, on the one hand, to characterise the working methodologies implemented by teachers in the use of the tool, either with the students or at the stage of test creation and assessment and, on the other, to investigate the real impact of the tool on the improvement of students' reading competence. Another aim of the study was to measure the degree of satisfaction of users, students and teachers, with the use of Letrinhas.

Given the importance that the work performed by students and teachers assumed in this study, greater focus has been placed on observation as it is an important source of data in qualitative studies and facilitates participant description (Patton, 2002). In this way, a detailed description has been done of the activities carried out in the 
Table 1. Rating for the creation and editing of text-reading questions (simple-complex)

\begin{tabular}{lccccccc}
\hline & \multicolumn{7}{c}{ Semantic Differential } \\
\cline { 2 - 8 } Descriptive Statistics & Simple & $\mathbf{2}$ & $\mathbf{3}$ & $\mathbf{4}$ & $\mathbf{5}$ & $\mathbf{6}$ & Complex \\
\cline { 2 - 8 } f & 10 & 9 & 7 & 3 & 4 & 0 & 0 \\
\hline \% & $30.3 \%$ & $27.3 \%$ & $21.2 \%$ & $9.1 \%$ & $12.1 \%$ & $0.0 \%$ & $0.0 \%$ \\
\hline Mean & & & & 2.5 & & & \\
\hline
\end{tabular}

Table 2. Rating for the creation and editing of word selection questions (simple-complex)

\begin{tabular}{lccccccc}
\hline & \multicolumn{7}{c}{ Semantic Differential } \\
\cline { 2 - 8 } Descriptive Statistics & Simple & \multicolumn{7}{c}{ Complex } \\
\cline { 2 - 8 } & $\mathbf{1}$ & $\mathbf{2}$ & $\mathbf{3}$ & $\mathbf{4}$ & $\mathbf{5}$ & $\mathbf{6}$ & $\mathbf{7}$ \\
\hline $\mathbf{f}$ & 8 & 11 & 7 & 5 & 2 & 0 & 0 \\
\hline $\boldsymbol{\%}$ & $24.2 \%$ & $33.3 \%$ & $21.2 \%$ & $15.2 \%$ & $6.1 \%$ & $0.0 \%$ & $0.0 \%$ \\
\hline Mean & & & & 2.5 & & & \\
\hline
\end{tabular}

course of the sessions using the tool, and these data have been complemented with those collected from the teachers in charge and the tutor in interviews and informal meetings held throughout the study, as well as the administration of surveys to measure usability and satisfaction.

The results of this study suggest a positive impact of Letrinhas on improving reading literacy of the participant students, as well as a high degree of satisfaction of the various actors involved, students, teachers and tutors. In fact, in addition to improving reading skills, it was found that its use allows to overcome the difficulty of learning to read in a shorter time-span, compared to data from previous school years.

\section{b) Opinion of users}

To obtain the opinion of teachers (future users) about the tool, a training session has been held at the Dr. Augusto César da Silva Ferreira secondary school, in Rio Maior, to demonstrate the functionality and usability of the tool. All participants had the opportunity to use the mobile application and the back-office. At the end of session, a questionnaire was distributed to participants which comprised questions about a wide range of topics such as the creation and edition of the questions, creation and edition of the tests as well as colours, icons, structure, navigation and overall design of the interface, the back-office and the application. To this end, we used a semantic differential scale ranging from 1 to 7 (Nielsen, 1993; LaLomia \& Sidowski, 1990). The participants were also asked to express their opinion about the tool and give suggestions for improvement. This questionnaire was validated by specialists and changes have been introduced based on the feedback obtained.

Training took place on 23 and 24 June 2016 and joined 33 participants: 81.8 percent female and 18.2 percent male.

As regards the age the mode is 44 years old, the minimum age is 34 years old, the maximum age is 58 and the mean 49 . We found that the vast majority of participants were teachers $(57.6 \%$ librarians, $36,4 \%$ teachers and $3 \%$ special education teachers). The only individual who was not a teacher was a file clerk.

The participant teachers taught different class levels: $28.1 \%$ in the third stage of basic education and secondary education, $31.3 \%$ in the 2 nd stage of basic education, $34.2 \%$ in the first stage of basic education, $3.1 \%$ at preschool and $3.1 \%$ in special education.

It turns out that the participants are already familiarised with educational software, with $36.4 \%$ of participants using it daily and $33.3 \%$ using it weekly. It is noted that $24.2 \%$ of participants use it sporadically and only $6.1 \%$ of participants have never used educational software. And most participants have already used mobile devices to teach $(63.3 \%)$.

Participants found the features of text creation/editing, and selection of words, word lists and multimedia very user-friendly. Table 1 on the evaluation of text creation and editing shows that the mean is 2.5 , the maximum value is 1 and the minimum value is 5 .

In Table 2 about the creation and editing of word selection questions, it turns out that the mean, the maximum value and the minimum value are the same of the creation and editing of text-reading questions.

As regards the evaluation of the creation and editing of multimedia questions (Table 3), the maximum and minimum value is equal to the one of text reading and word selection questions, but the mean is slightly higher (2.7). 
Table 3. Rating for the creation and editing of multimedia questions (simple-complex)

\begin{tabular}{lccccccc}
\hline & \multicolumn{9}{c}{ Semantic Differential } & & Complex \\
\cline { 2 - 8 } Descriptive Statistics & Simple & $\mathbf{2}$ & $\mathbf{3}$ & $\mathbf{4}$ & $\mathbf{5}$ & $\mathbf{6}$ & $\mathbf{7}$ \\
\cline { 2 - 9 } & 7 & 9 & 7 & 6 & 4 & 0 & 0 \\
\hline $\mathbf{f}$ & $21.2 \%$ & $27.3 \%$ & $21.2 \%$ & $18.2 \%$ & $12.1 \%$ & $0.0 \%$ & $0.0 \%$ \\
\hline $\mathbf{0}$ & & & & 2.7 & & & \\
\hline
\end{tabular}

Table 4. Rating for the creation and editing of word list questions (simple-complex)

\begin{tabular}{lccccccc}
\hline & \multicolumn{9}{c}{ Semantic Differential } \\
\cline { 2 - 8 } Descriptive Statistics & Simple & \multicolumn{7}{c}{ Complex } \\
\cline { 2 - 9 } & $\mathbf{1}$ & $\mathbf{2}$ & $\mathbf{3}$ & $\mathbf{4}$ & $\mathbf{5}$ & $\mathbf{6}$ & $\mathbf{7}$ \\
\hline $\mathbf{f}$ & 9 & 14 & 3 & 6 & 1 & 0 & 0 \\
\hline $\mathbf{\%}$ & $27.3 \%$ & $42.4 \%$ & $9.1 \%$ & $18.2 \%$ & $3.0 \%$ & $0.0 \%$ & $0.0 \%$ \\
\hline Mean & & & & 2.3 & & & \\
\hline
\end{tabular}

Table 5. Rating for test creation and editing in back-office (simple-complex)

\begin{tabular}{|c|c|c|c|c|c|c|c|}
\hline \multirow[b]{3}{*}{ Descriptive Statistics } & \multicolumn{7}{|c|}{ Semantic Differential } \\
\hline & Simple & & & & & & Complex \\
\hline & 1 & 2 & 3 & 4 & 5 & 6 & 7 \\
\hline f & 9 & 12 & 4 & 6 & 2 & 0 & 0 \\
\hline$\%$ & $27.3 \%$ & $36.4 \%$ & $12.1 \%$ & $18.2 \%$ & $6.1 \%$ & $0.0 \%$ & $0.0 \%$ \\
\hline Mean & & & & 2.4 & & & \\
\hline
\end{tabular}

Table 6. Rating for test correction in the back-office (simple-complex)

\begin{tabular}{lccccccc}
\hline & \multicolumn{9}{c}{ Semantic Differential } & & Complex \\
\cline { 2 - 8 } Descriptive Statistics & Simple & $\mathbf{2}$ & $\mathbf{3}$ & $\mathbf{4}$ & $\mathbf{5}$ & $\mathbf{6}$ & $\mathbf{7}$ \\
\cline { 2 - 8 } & $\mathbf{1}$ & 14 & 10 & 2 & 1 & 0 & 1 \\
\hline $\mathbf{f}$ & 5 & $42.4 \%$ & $30.3 \%$ & $6.1 \%$ & $3.0 \%$ & $0.0 \%$ & $3.0 \%$ \\
\hline $\mathbf{0}$ & $15.2 \%$ & & 2.5 & & & \\
\hline Mean & & & &
\end{tabular}

Table 7. Rating for back-office colours (agreeable-annoying)

\begin{tabular}{lccccccc}
\hline & \multicolumn{9}{c}{ Semantic Differential } & & Annoying \\
\cline { 2 - 8 } Descriptive Statistics & Agreeable & $\mathbf{2}$ & $\mathbf{3}$ & $\mathbf{4}$ & $\mathbf{5}$ & $\mathbf{6}$ & $\mathbf{7}$ \\
\cline { 2 - 8 } & 1 & 8 & 2 & 3 & 1 & 0 & 1 \\
\hline $\mathbf{f}$ & $54.5 \%$ & $24.2 \%$ & $6.1 \%$ & $9.1 \%$ & $3.0 \%$ & $0.0 \%$ & $3.0 \%$ \\
\hline $\mathbf{0}$ & & & 1.9 & & & \\
\hline Mean & &
\end{tabular}

Table 8. Rating for the suggestibility of back-office icons (Suggestive-Not suggestive at all)

\begin{tabular}{lccccccc}
\hline & \multicolumn{9}{c}{ Semantic Differential } \\
\cline { 2 - 8 } Descriptive Statistics & $\mathbf{1}$ & $\mathbf{2}$ & $\mathbf{3}$ & $\mathbf{4}$ & $\mathbf{5}$ & $\mathbf{6}$ & $\mathbf{7}$ \\
\cline { 2 - 8 } & 13 & 14 & 3 & 1 & 1 & 0 & 1 \\
\hline $\mathbf{f}$ & $39.4 \%$ & $42.4 \%$ & $9.1 \%$ & $3.0 \%$ & $3.0 \%$ & $0.0 \%$ & $3.0 \%$ \\
\hline $\mathbf{0}$ & & & & 2.0 & & & \\
\hline Mean & &
\end{tabular}

In the rating for the creation and editing of word list questions (Table 4), the maximum and minimum value are also equal to the rating for the remaining questions, but the mean is slightly lower (2.3).

Participants found test creation, editing and correction user-friendly. Table 5 containing the rating of text creation and editing shows that the mean is 2.4 , the maximum value is 1 and the minimum value is 5 .

As regards the rating for test correction (Table 6), the mean is 2.5 , the maximum value is 1 , with one individual rating it as 7 .

The participants found the back-office colours agreeable (Table 7), with 1.9 as the mean value, 1 as the maximum and 5 as the minimum.

The back-office icons were considered suggestive by the participants (Table 8), with the mean at 2 and the maximum value at 1 . There was, however, one individual that considered them not suggestive at all. 
Table 9. Rating for the back-office structure (simple-complex)

\begin{tabular}{lccccccc}
\hline & \multicolumn{7}{c}{ Semantic Differential } \\
\cline { 2 - 8 } Descriptive Statistics & $\mathbf{1}$ & $\mathbf{2}$ & $\mathbf{3}$ & $\mathbf{4}$ & $\mathbf{5}$ & $\mathbf{6}$ & $\mathbf{7}$ \\
\cline { 2 - 8 } & 11 & 11 & 8 & 1 & 1 & 0 & 1 \\
\hline $\mathbf{f}$ & $33.3 \%$ & $33.3 \%$ & $24.2 \%$ & $3.0 \%$ & $3.0 \%$ & $0.0 \%$ & $3.0 \%$ \\
\hline Mean & & & & 2.2 & & & \\
\hline
\end{tabular}

Table 10. Rating for the back-office navigation functionalities (simple-complex)

\begin{tabular}{|c|c|c|c|c|c|c|c|}
\hline \multirow[b]{3}{*}{ Descriptive Statistics } & \multicolumn{7}{|c|}{ Semantic Differential } \\
\hline & Simple & & & & & & Complex \\
\hline & 1 & 2 & 3 & 4 & 5 & 6 & 7 \\
\hline $\mathrm{f}$ & 12 & 13 & 4 & 3 & 1 & 0 & 0 \\
\hline$\%$ & $36.4 \%$ & $39.4 \%$ & $12.1 \%$ & $9.1 \%$ & $3.0 \%$ & $0.0 \%$ & $0.0 \%$ \\
\hline Mean & & & & 2.0 & & & \\
\hline
\end{tabular}

Table 11. Rating for the back-office interface design (agreeable-annoying)

\begin{tabular}{lccccccc}
\hline & \multicolumn{7}{c}{ Semantic Differential } \\
\cline { 2 - 8 } Descriptive Statistics & Agreeable & $\mathbf{2}$ & $\mathbf{3}$ & $\mathbf{4}$ & $\mathbf{5}$ & $\mathbf{6}$ & Annoying \\
\cline { 2 - 8 } & 1 & 10 & 6 & 0 & 1 & 0 & 0 \\
\hline $\mathbf{f}$ & $48.5 \%$ & $30.3 \%$ & $18.2 \%$ & $0.0 \%$ & $3.0 \%$ & $0.0 \%$ & $0.0 \%$ \\
\hline $\mathbf{0}$ & & & & 1.8 & & & \\
\hline Mean & &
\end{tabular}

Table 12. Rating for colour agreeableness (Agreeable-Annoying)

\begin{tabular}{lccccccc}
\hline & \multicolumn{9}{c}{ Semantic Differential } & & Annoying \\
\cline { 2 - 8 } Descriptive Statistics & $\mathbf{1}$ & $\mathbf{2}$ & $\mathbf{3}$ & $\mathbf{4}$ & $\mathbf{5}$ & $\mathbf{6}$ & $\mathbf{7}$ \\
\cline { 2 - 8 } & 18 & 13 & 1 & 1 & 0 & 0 & 0 \\
\hline $\mathbf{f}$ & $54.5 \%$ & $39.4 \%$ & $3.0 \%$ & $3.0 \%$ & $0.0 \%$ & $0.0 \%$ & $0.0 \%$ \\
\hline Mean & & & & 1.5 & & & \\
\hline
\end{tabular}

Table 13. Rating for the suggestibility of back-office icons (Suggestive-Not suggestive at all)

\begin{tabular}{lccccccc}
\hline & \multicolumn{9}{c}{ Semantic Differential } \\
\cline { 2 - 8 } Descriptive Statistics & Suggestive & $\mathbf{3}$ & \multicolumn{3}{c}{ Not suggestive at all } \\
\cline { 2 - 8 }$y$ & $\mathbf{1}$ & $\mathbf{2}$ & $\mathbf{3}$ & $\mathbf{4}$ & $\mathbf{5}$ & $\mathbf{6}$ & $\mathbf{7}$ \\
\hline $\mathbf{f}$ & 13 & 17 & 2 & 1 & 0 & 0 & 0 \\
\hline $\mathbf{0}$ & $39.4 \%$ & $51.5 \%$ & $6.1 \%$ & $3.0 \%$ & $0.0 \%$ & $0.0 \%$ & $0.0 \%$ \\
\hline Mean & & & & 1.7 & & & \\
\hline
\end{tabular}

The back-office structure was rated as simple by the participants (Table 9), with a mean of 2.2 and the maximum value of 1 . One individual considered it complex.

Also, the back-office navigation was rated as simple by the participants (Table 10), with a mean of 2 , the maximum value of 1 and the minimum of 5 .

Table 11 shows that participants considered the overall design of the interface agreeable, with the mean at 1.8, maximum value at 1 and minimum value at 5 .

The participants found the application colours agreeable (Table 12), with 1.5 as the mean value, 1 as the maximum and 4 as the minimum.

Also, the back-office navigation was rated as simple by the participants (Table 13), with the mean at1.8, the maximum value at 1 and the minimum at 4 .

The application's structure was rated as simple by the participants (Table 14), with the mean at 2 and the maximum value at 1 . There was, however, one individual that considered it complex. 
Table 14. Rating for the application's structure (simple-complex)

\begin{tabular}{lccccccc}
\hline & \multicolumn{7}{c}{ Semantic Differential } \\
\cline { 2 - 8 } Descriptive Statistics & $\mathbf{1}$ & $\mathbf{2}$ & $\mathbf{3}$ & $\mathbf{4}$ & $\mathbf{5}$ & $\mathbf{6}$ & Complex \\
\cline { 2 - 9 } & 12 & 15 & 4 & 1 & 0 & 0 & 1 \\
\hline $\mathbf{f}$ & $36.4 \%$ & $45.5 \%$ & $12.1 \%$ & $3.0 \%$ & $0.0 \%$ & $0.0 \%$ & $3.0 \%$ \\
\hline Mean & & & & 2.0 & & & \\
\hline
\end{tabular}

Table 15. Rating for navigation through the application (Simple-complex)

\begin{tabular}{|c|c|c|c|c|c|c|c|}
\hline \multirow[b]{3}{*}{ Descriptive Statistics } & \multicolumn{7}{|c|}{ Semantic Differential } \\
\hline & Simple & & & & & & Complex \\
\hline & 1 & 2 & 3 & 4 & 5 & 6 & 7 \\
\hline f & 13 & 14 & 3 & 2 & 0 & 0 & 1 \\
\hline$\%$ & $39.4 \%$ & $42.4 \%$ & $9.1 \%$ & $6.1 \%$ & $0.0 \%$ & $0.0 \%$ & $3.0 \%$ \\
\hline Mean & & & & 2.0 & & & \\
\hline
\end{tabular}

Table 16. Rating for the application's interface design (agreeable-annoying)

\begin{tabular}{lccccccc}
\hline & \multicolumn{7}{c}{ Semantic Differential } \\
\cline { 2 - 8 } Descriptive Statistics & $\mathbf{1}$ & $\mathbf{2}$ & $\mathbf{3}$ & $\mathbf{4}$ & $\mathbf{5}$ & $\mathbf{6}$ & Annoying \\
\cline { 2 - 8 } & 21 & 9 & 2 & 1 & 0 & 0 & 0 \\
\hline $\mathbf{f}$ & $63.6 \%$ & $27.3 \%$ & $6.1 \%$ & $3.0 \%$ & $0.0 \%$ & $0.0 \%$ & $0.0 \%$ \\
\hline $\mathbf{0}$ & & & & 1.5 & & & \\
\hline Mean & &
\end{tabular}

Table 17. Participants' opinion about the application

\begin{tabular}{lcc}
\hline Category & f & $\mathbf{\%}$ \\
\hline Great/Awesome/Excellent/Interesting/Very good/Good & 17 & $51.5 \%$ \\
\hline Motivating/Stimulating/Appealing & 7 & $21.2 \%$ \\
\hline Very useful & 3 & $9.1 \%$ \\
\hline Functional & 2 & $6.1 \%$ \\
\hline Effective & 2 & $6.1 \%$ \\
\hline With a lot of potential & 1 & $3.0 \%$ \\
\hline Eases the work of teachers & 1 & $3.0 \%$ \\
\hline Intuitive & 1 & $3.0 \%$ \\
\hline Should be available in all schools & 1 & $3.0 \%$ \\
\hline
\end{tabular}

Navigation through the application was rated as simple by the participants (Table 15), with the mean at 2 and the maximum at 1 . There was an individual who rated this question as 7.

Finally, the participants rated the back-office interface design as simple. Table 16 shows that the mean is 1.5 , the maximum value is 1 and the minimum is 4 .

The participants consider that it is simple to create and edit the questions and the tests, as well as correct errors. Participants liked the colours, the icons, the navigation structure and the overall design of the interface, with slightly better results for the application than for the back-office.

The final opinion of the participants on the application was quite favourable and the answers have been grouped in 9 categories. In the analysis of content, some answers have been allocated to more than one category. Most participants consider the Letrinhas a great, awesome, excellent, interesting, very good or good tool and more than $20 \%$ consider it motivating, stimulating or appealing.

Below are some comments from participants:

- "Excellent and exceptionally useful application. Congratulations!" (p008);

- "I was so pleased! I think it is an appealing and fantastic tool to facilitate the work of teachers and motivate students. Excellent job! Congratulations!" (P023)

- $\quad$ "It should be available to the majority of schools" (p009).

When questioned about improvements to make in the application, the participants focused on extending the information system to all subject matters, all education levels, all students, including those with special educational needs, and to all schools.

\section{School year 2016/2017}

Given the importance Letrinhas has assumed in the Artur Gonçalves cluster of schools, a project funded by the Ministry of Education has been added which covered all second graders with learning difficulties within the above- 
mentioned school cluster. In addition to the support to be given to classroom teachers and tutors who will be guiding these students, the School Library's staff will hold a training session in partnership with the Polytechnic Institute of Tomar. It is thought that in this way, in addition to learning about the information system, teachers will be able to create a battery of tests by type of difficulties, which will facilitate the work to be done in the context of the classroom, with advantages for all students involved because the use of mobile devices and their multimedia capabilities contributes significantly to students' motivation and autonomy (Manso et al., 2015).

\section{CONCLUSION AND FUTURE WORK}

Reading literacy is critical to the academic success of students, but for some children it is a very complex process, so that difficulties can arise in this area that should be identified as soon as possible (Silva, 2003; Smith, 2003). And it was to address these difficulties that this internationally-recognised information system was created.

The results indicate a high degree of satisfaction with this information system as well as a positive impact on improving the reading skills of students, which suggests a direct relationship between the use of Letrinhas and the improvement of reading literacy in the participating students.

This positive assessment, as well as new needs identified by the participating teachers, have allowed the development of the information system that currently has features adaptable to any grade and any subject. Furthermore, the fact that Letrinhas can be used on mobile devices significantly contributes to extend its scope of use from the classroom to an autonomous use by the student at home, for example. It is up to teachers, then, to draw their learning scenarios, tailored to individual students, and to use the various tests provided by Letrinhas in order to create new learning environments that are more appealing and promoters of creativity and autonomy, thus contributing to the academic success of our students.

Given the huge potential of such systems to combine mobile technology with learning strategies, it is anticipated that next school year some classes in the Torres Novas cluster will be using the tool and its use will be monitored. Thus, at the end of the next school year, data will be collected to evaluate not only the use of Letrinhas and all its new features by the different actors, but also its impact on improving student learning.

\section{ACKNOWLEDGEMENTS}

We would like to thank Alexandre Carvalho, Artur Gomes, Cristiana Pereira, Renato Pestana and Tiago Fernandes, undergraduate students of the computer engineering degree from Polytechnic Institute of Tomar for their contribution to the project.

\section{REFERENCES}

Autoridade Nacional de Comunicações [ANACOM] (2016). Serviços Móveis: Informação Estatística. $2 .^{\circ}$ Trimestre de 2016. Lisboa: ANACOM.

Bergmann, J. and Sams, A. (2012) Flip your Classroom: Reach Every Student in Every Class Every Day. International Society for Technology in Education.

Bergmann, J. and Sams, A. (2014) Flipped Learning: Gateway to Student Engagement. ISTE.

Buescu, H., Morais, J., Rocha, M. and Magalhães, V. (2015) Programa e Metas Curriculares de Português do Ensino Básico. Lisboa: Ministério da Educação e da Ciência.

Carvalho, A.C. (2011) Aprendizagem da leitura: Processos cognitivos avaliação e intervenção. Viseu: Psicosoma.

Coutinho, J. (2013) mLearning: Ambiente de Aprendizagem com Interface Adaptativo. Master Thesis. Lisboa: Universidade de Lisboa.

Cruz, V. (2005) Uma abordagem filogenética e ontogenética à aprendizagem da leitura e escrita, Sonbar, 2, pp. 199228.

Foorman, B.R., Francis, D.J., Shaywitz, B.A. and Fletcher, J.M. (1997) The case for early reading intervention. In B. Blachman, ed., Foundations of reading acquisition and dyslexia (pp. 243-264). New Jersey: Erlbaum.

Geddes, S.J. (2004) Mobile learning in the 21st century: benefit to learners. Available at: https://goo.gl/FytECi (Accessed 17 February 2012).

Lalomia, M. and Sidowski, J. (1991) Measurements of Computer Attitudes: A Review, International Joumal of HumanComputer Interaction, 3(2), pp. 171-197.

Lamas, E. and Neto, M. (2015) Tecnologias digitais de leitura e escrita: Contributos para uma aprendizagem motivada, Revista de Estudios e Investigación en Psicologia y Educación, 8, pp. 141-144. 
Lan, Y.-J., Sung, Y.-T. and Chang, K.-E. (2007) A mobile-device-supported peer-assisted learning system for collaborative early EFL reading, Language Learning \& Technology, 11(3), pp. 130-151.

Larson, L.C. (2007) A case study exploring the "new literacies" during a fifth-grade electronic reading workshop, PhD Thesis. Manhattan, Kansas: Kansas State University.

Li, X. and Atkins, M. (2004) Early Childhood Computer Experience and Cognitive and Motor Development, Pediatrics, 113(6), pp. 1715-1722.

Lopes, J.A. (2005). Dificuldades de aprendizagem da leitura e da escrita: Perspetivas de avaliação e intervenção. Porto: Edições Asa.

Manso, A., Marques, C.G., Dias, P., Ferreira, A. and Morgado, F. (2015) Letrinhas: promoting reading through mobile devices, In M. R. Rodrigues, M. L. Nistal and M. Figueiredo, ed., 2015 International Symposium on Computers in Education (SIIE) (pp. 56-61). New York, NY: IEEE.

Mellati, M. and Khademi, M. (2015) The Impacts of Distance Interactivity on Learners' Achievements in Online Mobile Language Learning: Social Software and Participatory Learning. International Journal of Web-Based Learning and Teaching Technologies, 10(3), pp. 19-35.

Moura, A. (2010) Apropriação do telemóvel como ferramenta de mediação em mobile learning: estudos de caso em contexto educativo. $\mathrm{PhD}$ Thesis. Braga: Universidade do Minho.

Nielsen, J. (1993) Usability Engineering. London: Academic Press.

Organização das Nações Unidas para a Educação, Ciência e Cultura [UNESCO] (2014). Diretrizes de politicas para a aprendizagem móvel. Paris: UNESCO.

Patton, M. (2002) Qualitative research and evaluation methods. London: Sage Publications.

Pellerin, M. (2014) Using Mobile Technologies with Young Language Learners to Support and Promote Oral Language Production, International Journal of Computer-Assisted Language Learning and Teaching, 4(4), pp. 14-28.

Pinheiro, C. (2016) Dispositivos Móveis na Educação. In II Encontro da Rede de Bibliotecas de Bragança. Ler o mundo: passaporte para o future, Bragança: Rede de Bibliotecas de Bragança.

Poll, H. (2014) Pearson Student Mobile Device Survey 2014. Pearson.

Richardson, U. and Lyytinen, H. (2014) The Graphogame Method: The theoretical and methodological background of the technology-enhanced learning environment for learning to read. Human Technology, 10(1), pp. 39-60.

Shaywitz, S. (2008) Vencer a dislexia: como dar resposta às perturbacões da leitura em qualquer fase da vida. Porto: Porto Editora, 2008.

Silva, A.C. (2003). Até à descoberta do princípio alfabético. Lisboa: Fundação Calouste Gulbenkian.

Sim-Sim, I. (1995) Desenvolver a Linguagem, Aprender a Língua. In A. Carvalho, ed., Novas Metodologias Educativas (pp. 197-236). Porto: Porto Editora.

Smith, F. (2003) Compreendendo a leitura: uma análise psicolinguística da leitura e do aprender a ler. Porto Alegre: Artemed.

Sterling, G. (2016) All digital growth now coming from mobile usage — comScore. Marketing Land. Available at: https://goo.gl/ee1t8C (Accessed 24 June 2016).

Thoermer, A. and Williams, L. (2012). Using Digital Texts to Promote Fluent Reading, The Reading Teacher, 65(7), pp. 441-447.

Velasquez, M. (2007) Percursos Desenvolvimentais de Leitura e Escrita - Estudo longitudinal com alunos do $1 .^{\circ}$ ciclo do ensino básico. PhD Thesis. Braga: Universidade do Minho. 